\title{
Building partnership through partnership: Reflections on the role of post-baccalaureate fellows in program development
}

\author{
Leslie Ortquist-Ahrens, Center for Teaching and Learning, Berea College, USA. \\ Contact: ortquistahrensl@berea.edu
}

Launching new student-faculty pedagogical partnership programs can be daunting at institutions that have had no prior experience with these fruitful, enlivening, and even countercultural initiatives. When my colleagues and I set out in early 2017 to develop such a program at Berea College in Kentucky (USA) under the aegis of a large grant-funded institutional initiative, we asked ourselves questions others may also have: How can someone who has never participated in such partnership craft a successful program for others? How can busy educational developers or equally busy faculty members add another large project to the slate? And how can they convince a cash-strapped administration to support the work and possibly fund the staffing to institutionalize it?

The approach we took involved creating a post-baccalaureate (post-bacc) fellow position. Post-bacc fellows are recent graduates of 4-year colleges and universities who take on paid positions that typically last 1 to 2 years. Such positions are usually research focused, but they can be adapted to support program development. At the suggestion of the consultant we hired through our grant, Alison Cook-Sather, who is the director of Students as Learners and Teachers (SaLT), a student-faculty pedagogical partnership program at Bryn Mawr and Haverford Colleges, a faculty colleague, Anne Bruder, and I hired two post-bacc fellows to collaborate with us to develop Berea's program. We were also inspired by the first post-bacc fellow for pedagogical partnerships created at Trinity University to support the development of their pedagogical partnership program (Abbot in Cook-Sather et al., 2019).

In this essay, I reflect from my perspective on the story of the post-baccs' critical role in establishing the program and draw on reflections shared with me by Anne, who participated in the SaLT program (Bruder, 2020) when she was a post-doctoral fellow at Bryn Mawr College. I also integrate reflections shared with me by the first post-bacc fellow who worked with us for the 2017-2018 academic year, Khadijah Seay, who completed her undergraduate degree at Bryn Mawr College in 2016, and the second post-bacc fellow who worked with me for the 2018-2019 academic year, Mia Rybeck who graduated from Haverford College in 2017. Both had been student partners in the SaLT program as undergraduates. Three experienced pedagogical partners thus helped me co-create simultaneously-through partnership-Berea's version of a post-bacc fellow position and Berea's pedagogical partnership program. 


\section{BACKGROUND}

At my former institution in the early 2000s, I attempted to introduce an initiative modeled on Brigham Young University's Students Consulting on Teaching (SCOT) program (Sorenson, 2001), which involved training students to provide one-time class observations or midterm-assessment focus groups in classes. However, the initiative failed to garner necessary interest and buy-in largely because of faculty discomfort consulting with an unfamiliar student. Eager to find a different model once I arrived at Berea in 2012, I looked to the SaLT program. I thought Alison's approach would appeal culturally at a small college because of the program's strong relational nature and obviate the need to repeatedly drum up interest in one-time consultation opportunities with relative strangers by anchoring the work between students and faculty in sustained relationships built on the bedrock of trust and familiarity.

Berea's pedagogical partnership program adopted many features from the SaLT program. A student who applies and is selected pairs with a faculty member who elects to participate; the student participant observes their partner's target class for 1 hour each week and takes detailed ethnographic notes; then faculty-student pairs meet weekly for an hour to discuss the notes, specific goals for future observations, and the student partner's insights and recommendations for potential changes. Unlike in SaLT, Berea students cannot receive workstudy pay for their time, given Berea's status as a federally funded Work College; instead, students take a semester-long, one-credit course to learn about higher education teaching, learning, and pedagogical partnership. Faculty participate in a multi-session community of practice to debrief with a facilitator and peers.

Today, just 5 years into our endeavor, Berea has a fully developed program embedded in the Center for Teaching and Learning (CTL). It was endowed in its third year by a donor captivated by the program. By the end of spring 2021, 47 instructors (representing $24 \%$ of the college's continuing faculty plus others who have moved on) and 51 students will have participated. Already after the first year, we saw robust evidence of outcomes identified in the research: increased faculty and student engagement, motivation, and learning, together with an enhanced appreciation for the challenge and craft of teaching; heightened metacognitive awareness, a strengthened sense of identity, and a deepened experience of belonging for students, especially traditionally underserved students; increased faculty attention to diverse student needs and respect for student voice; and, for students, a renewed commitment to their responsibility for learning (Cook-Sather, 2020; Cook-Sather et al., 2014, Mercer-Mapstone et al., 2017). Five years ago, we would have been incredulous at how rapidly we could institutionalize such a program. Khadijah and Mia, through their concentrated focus, administrative labor, deep personal experience-and leadership in partnering with me and Anne-were indispensable to this growth and our success.

\section{LEARNING ABOUT POST-BACC FELLOWS}

Soon after I was hired in 2012, I met Anne, who, because she had found the SaLT program transformative when a junior faculty member, envisioned partnering to bring a similar opportunity to colleagues at Berea. Despite our own extensive experience in program-building, neither of us had built this kind of a program. The two of us nevertheless nurtured the dream, ran a pilot attempt, then seized the opportunity to embed the initiative in a large Mellon grant (a national foundation grant supporting higher education, the humanities, and the arts) focused 
on student belonging, one of the key outcomes of partnership work. Both of us were elated to have funding - and then befuddled about how to bring the program into being.

When Alison, our grant consultant, recommended hiring an experienced post-bacc fellow who could leverage her student partner experience and bring key expertise and skills to bear on building and running the program, Anne and I were pleased to have some advice. But initially, Alison's suggestion baffled us. We were unsure how a recent college graduate, however strong, would be positioned to help establish a new program in a new institution. I anticipated I would need to lay out the plan and incremental steps for the post-bacc, but it was precisely that work I couldn't imagine.

Moreover, as an active half-time tenured faculty member in English, directing the partnership project in my role as CTL director, which included not only my area of educational development (as the sole faculty developer at the college), but also the college's Writing Center and teaching assistant development program, I worried that I would be hard pressed to be a good and available supervisor. I wanted some genuine help to envision and build. My fear was that I might simply end up with an additional very junior staff member to mentor, direct, and supervise, meaning that at the end of the day it would be harder and more time consuming to launch a program than had I gone it alone.

Anne and I didn't grasp then that the post-bacc fellows could not only participate in and often lead the programmatic and managerial heavy lifting, but that they would teach us how to be in partnership with them not as junior staff members but as colleagues. We were humbled. And we learned an important lesson about partnership through this component of the work together across 2 years.

\section{CO-CREATING OUR OWN POST-BACC MODEL}

In the initial year of the 2-year fellowship written into the grant, Khadijah, our first postbacc, brought a wealth of managerial skills, the lived student reality of partnership, and extensive previous experience helping to support and build major institutional diversity initiatives at Bryn Mawr together with faculty and administrators. She shared with me that, through these experiences, she came "to understand the perspectives of different constituents, learning to balance the needs of the institution with the needs of the students, which often meant balancing the practical with the emotional." For Khadijah, it was fundamental to help students feel a sense of belonging on campus so they could negotiate differences of power as they sought to have better educational experiences. Equipped with transferable skills, relevant experience, and thoughtful perspectives, Khadijah was able to walk into a new (and relatively undefined) staff position and take a leading role in the instructional, administrative, and logistical work of co-developing the course and the program with me and Anne (who continued in co-leadership with us through the fall of 2017).

Khadijah began by developing some institution-specific supporting materials for recruiting, vetting, and choosing student participants, and by adapting others from resources Alison had shared (e.g., guidelines, a program description, an application form and process, promotional materials, etc. - all available in Cook-Sather et al., 2019). Once she became acquainted with our course-based model, which was different from her experience at Bryn Mawr, Khadijah collaborated closely with me as the instructor of record to suggest topics, a sequence for class sessions, and short readings. She built and maintained the course site in 
Berea's learning management system, drafted weekly agendas, and initiated class meetings with informal check-ins with the student partners, setting and maintaining an atmosphere of respectful ease and curious comfort.

It was an eye-opener for me to work with Khadijah and to let her take the lead, even in class. Khadijah slowed the pace to emphasize trust- and community-building, something I have long valued in teaching but never practiced as deeply as she modeled. She, as a near peer, was easily able to imagine her way into the students' perspectives and sense of vulnerability in the project, something no longer fully available to me given my generational distance from them. While Anne and I had been uncertain what responsibilities Khadijah would want to-or couldtake on, by the end of the first semester, it became easy to entrust her with responsibility for the overarching program and its upkeep, as well as for co-teaching-something we had not anticipated initially.

In the spring, Khadijah promoted the fall program and helped recruit a diverse student cohort-an important program and grant goal. She also oversaw the application and selection process while working with me to manage rapid program growth. Finally, Khadijah contributed written reflections for our grant reporting process at year's end.

Shifting roles and stepping away from program co-leadership, Anne joined the second cohort in spring as a participant, eager to engage anew with a student partner, and found, the second time, like the first, that partnership work was about "ceding control and leaping into a space with an unpredictable outcome" (Bruder, 2020, p. 229). That, in a phrase, was what both Anne and I experienced as program initiators, and what I continued to experience as a project director and instructor, as we leapt into partnership first with one, then with the second postbacc fellow.

Beyond these instrumental supports, Khadijah brought to the program a spirit of affirmation and abiding respect for all participants. She infused the course and our partnership with her powerful insights and perspectives about the program's essential character, and she led authentically by embodying those values. As she put it, "I aimed to model being vulnerable for student and faculty partners in our meetings and to seek normalcy in human interaction. As a professional, I've shown up as myself, whole and imperfect, and encouraged the students I work with to do the same."

When Khadijah decided to return to Philadelphia after a year of helping lay the groundwork and running the program, the entire CTL staff understood and cheered her on but greeted the news with deep regret and sadness. And I, just a year after wondering how a recent college graduate could lead and lift, wondered how I could possibly continue without her! Khadijah had, however, established such a strong foundation and taught me so many unexpected lessons about experiential learning, trust, and letting go, that the way was paved to work with a new post-bacc fellow. Just before the 2018-2019 academic year began, Mia responded to our invitation to apply and agreed to join us for the final year of the grant-funding for the position.

During her campus visit, Mia observed the spring semester's last course. This allowed her, as she shared with me, to "witness the dynamic community" we had co-created. Mia reflected that the "palpable" respect between all program participants and facilitators convinced her to take the job. Like Khadijah, Mia brought keen skills of observation, facilitation, and engaged reflection to the program. Notably, she also initiated a partnership with me in one 
of my English courses in a more traditional student partner role. In this way, she concurrently worked with me both in my role as an educational developer (to build the program) and in my role as a faculty member (to reflect on my own practice). As Mia put it, "through our own pedagogical partnership, we practiced what we were facilitating with students and faculty."

While Khadijah's foundational work gave Mia an established place to begin her own, the program was new enough that she had a real hand in shaping its continued development using her unique expertise and gifts. She revisited and refined materials; she co-taught the course and worked to rethink parts of it; and she introduced opportunities for faculty participants to consult with her about their partnerships. Mia brought art to the course's syllabus; enhanced the course with an explicit emphasis on belonging through an extended unit she developed, grounded in bell hooks's 2008 book of the same title; and invited students into writing a collaborative essay about partnership and belonging which has yet to be published. Finally, Mia helped us solve a problem that can scuttle any initiative: making it sustainable-specifically, without post-bacc fellows.

\section{CARRYING OUR PROGRAM FORWARD POST POST-BACC}

Mia and I determined three pressing needs at the end of the post-bacc period: (a) recruiting students, (b) managing the application process, and (c) maintaining a foregrounded role for a student partner voice in the leadership of the program. Responsibility for recruiting and application management shifted to a staff member in the CTL. But we insisted on maintaining strong student leadership in the program. That could happen by identifying a past participant to serve each year as the Mellon Fellow for Student-Faculty Partnerships who would help co-plan and lead future classes. When Mia departed in summer 2019, the program had wings. As was true with Khadijah before her, we grieved her loss, even as we wished her well on the next phase of her journey. We were off!

\section{FINAL THOUGHTS}

I turn here to offer final thoughts about what we learned-things we would have wanted to know, had we not known Alison, who recommended candidates and advised us all along the way-and to take one last reflective look at my own growth through working in these partnerships.

The post-bacc approach is relatively young, so pathways for institutions and would-be fellows are only slowly emerging. Ideally, as more institutions host successful programs, there will be a greater pool of potential post-baccs to recruit and perhaps a formal pipeline for recruiting candidates. Until then, I offer the following advice.

First, for those considering employing a fellow to help with program development, I recommend the open-source book Pedagogical Partnerships (Cook-Sather et al., 2019), which features a "Book Resources" section, including a backward-design template for creating a postbacc fellow position.

Second, what we didn't know to list on our own job description, but which was at the heart of the work and key to success, involved conveying, representing, and embedding the values and ethos of partnership work in the new program-beginning with helping us experience being in partnership with the post-bacc. Knowing what we know now, we would list that as an important job responsibility. Perhaps the first one. 
Third, I recommend considering opportunities for post-bacc fellows beyond program development-and urge parallel reflection on the different role a program director might play in supporting these. While both post-bacc fellows were busy across the year with official position-related responsibilities, they had open time we hadn't anticipated. To honor the spirit of a fellowship, we invited each to develop a project of interest. For this work, it was important for me to be a conversation partner, mentor, and supervisor-in a more traditional, somewhat more asymmetrical role. Helping a young professional navigate a new institutional context and role, especially to build relationships and credibility on campus, was important, and both Khadijah and Mia looked to me for guidance. In this way, I found the balancing act between supervision and partnership an ongoing challenge: when to be a partner, when a mentor/supervisor?

How did I grow through this partnership work? Though, unlike Anne, Khadijah, and Mia, I had never been in a bona fide pedagogical partnership before, I had been confident I grasped the concept and practice. After all, I had shared power with students in classrooms for years and invited faculty in development to co-create the agenda. But this case was different. At first it was difficult to know how much and where to defer to the post-bacc fellows' leadership. Prompted to re-examine my assumptions about expertise, I eased into reconceiving the relationship with each post-bacc fellow not only as a supervisor but more fundamentally as a partner.

With time I realized that being a partner to the post-bacc didn't mean I gave up either my own legitimate areas of strength and experience (just as is true for faculty in partnerships with students), nor did I stop being a mentor and supervisor, but it did mean that I needed to make space. And to trust, as Anne had trusted her student consultants in both her partnerships. It dawned slowly on me that doing so was essential if the program we were building was to embody the larger ethos of partnership based on the premises of respect, reciprocity, and responsibility (Cook-Sather et al., 2014).

I had imagined the grant would pave the way for me, together with these colleagues, to set up a program for others to engage in partnership. Yet, I had failed to realize how important it was for me to loosen my hold on the project and to trust my new colleagues by recognizing them as partners and empowering them to do the work they had come to Berea to do. This was the gift the post-bacs fellows were uniquely poised to give.

\section{ACKNOWLEDGEMENTS}

My deepest thanks to Anne Bruder, Khadijah Seay, and Mia Rybeck for their partnership and for their many contributions to this reflective essay and to Alison Cook-Sather for supporting our work and offering feedback on drafts of this essay. Continued gratitude goes to the Andrew W. Mellon Foundation and our anonymous Berea donor for generously funding this work.

\section{NOTE ON CONTRIBUTOR}

Leslie Ortquist-Ahrens, Ph.D., is associate professor of comparative literature and directs the Center for Teaching and Learning at Berea College (Kentucky, USA). As a practitioner and a scholar, she is interested in mentoring and coaching, collaborative learning, and communities of 
practice. Currently, programming for new faculty and the Student-Faculty Partnership Program are cornerstones of her work.

\section{REFERENCES}

Bruder, A. (2020). Sitting on rocks, human knots, and other lessons I learned in partnership. In L. Mercer-Mapstone \& S. Abbot (Eds.), The power of partnership. Students, staff, and faculty revolutionizing higher education. Elon University Center for Engaged Learning Open Access Series. https://doi.org/10.36284/celelon.oa2

Cook-Sather, A. (2020). Respecting voices: How the co-creation of teaching and learning can support academic staff, underrepresented students, and equitable practices. Higher Education, 79(5), 885-901. https://doi.org/10.1007/s10734-019-00445-w

Cook-Sather, A., Bahti, M., \& Ntem, A. (2019). Pedagogical partnerships: A how-to guide for faculty, students, and academic developers in higher education. Elon University Center for Engaged Learning Open Access Series. https://doi.org/10.36284/celelon.oa1

Cook-Sather, A., Bovill, C., \& Felten, P. (2014). Engaging students as partners in learning and teaching: A guide for faculty. Jossey-Bass.

Mercer-Mapstone, L., Dvorakova, S. L., Matthews, K. E., Abbot, S., Cheng, B., Felten, P., Knorr, K., Marquis, E., Shammas, R., \& Swaim, K. (2017). A systematic literature review of students as partners in higher education. International Journal of Students as Partners, 1(1). https://mulpress.mcmaster.ca/ijsap/article/view/3119

Sorenson, D. L. (2001). College teachers and student consultants: Collaborating about teaching and learning. In J. E. Miller, J. E. Groccia, \& M. S. Miller (Eds.), Student-assisted teaching: A guide to faculty-student teamwork (pp. 179-183). Anker. 